\title{
Critical Thinking, Creativity and Gender Differences for Knowledge Generation in Education
}

\author{
Ivanna Shubina, Atik Kulakli \\ American University of the Middle East, Kuwait
}

\begin{abstract}
This paper aims to discover the relationship between critical thinking and creativity and empirically measure the level of their development among youngsters for knowledge generation and dissemination in education. Authors attempted to explore the relationships between critical thinking and creativity from both theoretical and empirical perspectives. The research background was constructed by relevant literature review on creative potential, critical abilities, as well as relationships between them and their role in learning processes along with knowledge acquisition and management.

In order to empirically investigate the relationships between the variables, the authors performed a survey, gathered the data (findings) and conducted statistical analysis with using SPSS software. This research as preliminary study concentrates to explore the quality of the relations between the variables among young generation (220 participants: 86 female, 134 male).

The primary findings show that existing relationships between all studied constructs are complex and influenced by other variables such as personality, social environment, educational system, technology usage and knowledge generation, teacher's philosophy etc. It was discovered that gender has a significant impact on critical thinking skills and creativity. Therefore it ensures of knowledge creation and sharing in modern educational era.

Keywords: critical thinking, creativity, empirical analyses, education technology and knowledge generation, knowledge dissemination, gender.
\end{abstract}

\section{Introduction}

The theoretical and empirical studies in the last few decades have indicated that creativity is a significant and powerful factor in the personal, academic or professional achievements. Although those constructs have been explored by researchers independently within various fields, only few comparative studies concentrated to analyze the relations among them.

It is identified that high critical thinking skills may enhance creative abilities and vice versa [2]. It has been stated that both critical and creative thinking are conditions for purposeful thinking [5].

Thinking skills are influenced by external factors such as educational paradigm, teaching approach and method, assessments' nature, teacher's feedback, emotional atmosphere, positive attitude [10], [11], [13].

Among internal factors researchers explore selfdetermination, intelligence, emotional state, positive self-image, personality traits and cognitive abilities etc. [10], [12], [16].

Many studies were conducted on the relationships between gender and critical thinking. Gender and creativity [4], [17], [18], [20]. Those studies considered various measurement scales, different type of task or different participant's age. Some studies indicated significant role of gender in differentiating creative potential and critical thinking skills, while other did not support hypothesis about significance of gender.

The main objective of current study is to explore the connections between creativity and critical thinking abilities both in theoretical and empirical perspectives among males and females. The results of the relation of those variables need to be related to the knowledge generation process. In particular, this study addresses the following broad research questions such as;

- "Is there a significant correlation between critical thinking and creativity?",

- "Does gender has influence on creativity or critical thinking?", and

- "How knowledge generation and dissemination related those issues?"

\section{Literature review}

\subsection{Relationship between critical thinking and creativity}

At first sight, critical thinking and creativity can be perceived as mutually exclusive concepts. Researchers from various fields attempted to analyze the potential connections between two types of thinking; critical thinking and creativity [2], [5]. Those studies can be viewed as dichotomy approach or complimentary approach. The radical dichotomy 
approach defines those two types of thinking as contradictory. According to this perspective, critical thinking may be developed while solving tasks or problems within a specific domain when students need to apply analytic, selective, evaluative, and rulebased abilities. Creative thinking usually goes beyond the context or specific domain, being imaginative, generative, spontaneous, inventive and nonevaluative. The complementary approach promotes the idea to teach both critical and creative thinking skills as interrelated cognitive abilities. For instance, thinking critically plays an essential role in a field of innovations, when individual creates new product idea and set proper strategies which would not be simply novel but also valuable. Skills such as critical judgment, evaluating of alternatives, selection of information, assessing reliability etc. are definitely involved in creative process [2]. However, it is impossible to separate the critical thinking and creativity in reality.

\subsection{Critical thinking and creativity in educational system}

The combination of pedagogic, psychological and social factors can become a supportive factor for creativity and critical thinking development. Educational system can prepare teachers, develop assessments and grading rubrics, develop methodology and policy which altogether will enhance creativity and critical thinking development among students.

\subsubsection{Supportive factors for critical thinking and} creativity development. Creativity and critical thinking has to be reinforced among students as interrelated cognitive processes which may enhance different types of thinking, productivity and applicability of gained knowledge and experience [9], [13].

The special interest has to be focused on promotion of teaching which supports collaborative teacherstudent relationships. Therefore, it establishes a relevant emotional atmosphere in a classroom, and motivates students to provide inventive and original ideas.

Modern researchers [11] demonstrated the importance of focusing on so-called "Mini-c" creativity, which can be analyzed at personal level and measured by novelty and uniqueness of person's approach to understand the events or experiences. Moreover, "Mini-c" creativity should be the most integrated educational system including all the levels [13].

The nature and structure of tasks or assessments given to student's have a significant impact on students' potential development. Recent studies show that teaching through involving students into the game-like situations significantly increase their desire to take intellectual risk which is crucial for creativity.

There is a significant relation between motivation and creativity. Studies showed that intrinsic motivation can reinforce creativity, while extrinsic motivation may inhibit it. Additionally, perceiving a reward as a "bonus" reinforces intrinsic motivation and results in being more effective thinkers. The other study stated that, low-thinking-skill students demonstrated higher creativity when expecting evaluation in comparison with high-thinking-skill students [10].

Although, there are studies showing some negative influence of rewards to students' motivation, some of researchers delivered evidences of its positive influence [10]. Actually, spirit of competitions and proper rewards can enhance both team and individual motivation to be more creative [16]. Moreover, using of rewards may have ambivalent influence on the students' performance and achievements, dividing their attention and demotivating for choosing a challenging task, taking intellectual risk or being involved into creative expression.

Feedback that students receive from their teachers carries a motivational aspect which can enhance creativity and critical thinking among young people. It is common to choose and exhibit the "best" product as a motivating strategy. However, it has to be emphasized that creativity is reinforces by drives belonging to intrinsic motivation such as involvement, curiosity, enjoyment, interest and personal challenge. Another research of Sternberg's Intelligence models [12] considers three processing skills (analytical, creative, and practical) as an essential impact on the development of successful intelligence. Combination of different types of cognitive skills and abilities are important for enhancing of effective thinking, when students need to generate a novel and appropriate solution, analyze alternatives, solve a problem, and make efficient decision. In this matter, it is extremely important to perceive creativity and critical thinking as a central cognitive process in education, where creativity has to be combined with practical and analytical skills in teaching [13].

Encouraging students to think independently, to be spontaneous and initiative in combination with developing of students' potential will result in critical thinking and creativity enhancing. Beneficial for students' potential development is applying such methods as learning through discovery, heuristic approach, problem-solving, learning through research. As a matter of fact that expanding and practicing with students' imagination may raise their cognitive capabilities and self-efficacy. Students are lessen their fear of unknown experiences [10].

In addition, positive emotional state, positive self-image and openness to experience are associated with avoidance of psychologically uncomfortable 
feelings and encouraging students to be more creative in terms of working on their own potential, utilizing various experiences. It could also be said that high self-efficacy is linked with greater effectiveness in thinking and creativity. Although all of the mentioned determinants are significant for creativity and critical thinking as demonstrated in various studies, the relation among them is not clear [14].

\subsubsection{Barriers for critical thinking and creativity} development. Social role of teacher provides specific experience and shapes traditional way of thinking, as well as appropriate attitudes, beliefs and assumptions regarding educational processes which may enhance or suppress development of creative potential and critical thinking among learners [7]. Traditionally, teachers are concentrated on one-way transmitting information, expecting students to answer their questions and simply reproduce transferred information [13], [14]. In addition, the contemporary educational system expects from teachers to follow provided external standards and programs, standardized assessments and teaching philosophy, which usually do not include specific learning standards or outcomes for both creativity and critical thinking [29]. Altogether, mentioned above factors may inhibit development of creativity and critical thinking in the educational system.

In reality, educators are more focused on critical thinking development through understanding the reasoning, solving problems effectively, assessing independently and appropriately. Neglecting the development of creativity can result in lack of effective thinking among students. Various researchers emphasize the important role of creativity in a learning process.

Some studies have been shown that the teachers might have lack of understandings of creativity [6] or associating creativity with originality only [8]. As a result students' potential meets many obstacles on the way of its expression, evaluation and development.

Cognitive skills development can be suppressed if educational conditions are supported by extrinsic motivation only, including competitions, rewards, social comparison and social judgments. Furthermore, comparison to achievements of others and based on its evaluation may cause negative feeling and result in decreasing of students' desire and capabilities for creative thinking [8], [16]. Additionally, studies conducted by cognitive psychologists proved negative impact of extrinsic motivation (i.e. expected reward or evaluation) on creativity [7], [13].

\subsection{Critical thinking and creativity: gender differences.}

The relationships between 'gender and creativity', 'gender and critical thinking' have not been precisely discovered. Although critical thinking is reported in contemporary literature broadly, the relation between gender and critical thinking is not explored deeply. A study examining problem solving and gender [17] found that gender differences for adolescents were not statistically significant.

Walsh and Hardy found that in a comparison of academic majors and gender from Facione's California Critical Thinking Disposition Inventory, female scored higher than males in following scales: open-mindedness and maturity [20].

Study on critical thinking ability [18] shows that gender differences are significant at high level critical thinking skills ability, while at moderate or low levels those difference are not significant.

Other studies stated, that females and males do not differ in critical thinking scales inference and deduction, what was in agreement with Halpern's study [1], stating that critical thinking could be developed through gaining experience or transferring the knowledge to others.

Torrance argues that there was no gender difference in performance at tests, measured creative potential, but there were some significant differences between genders in self-perception: female did not perceive themselves as inventors and were strongly influenced by their environment [15].

Another study [4] demonstrated that statistically significant differences on the majority of subtests between females and males with women prevalence. This study indicated the gender differences between students in year 8 were higher that among students in year 11 .

\subsection{Knowledge generation in relation with educational technologies}

Recent communication platforms and technologies such as internet and social web in educational domain are becoming the major infrastructure for knowledge creation and exchange among new generations of students [3]. Although knowledge has been created and disseminated in various ways such as written and oral, story-telling forms over the centuries, it became more complex and widely dispersed around the globe. The nature of the new technologies provide enormous alternatives to individuals as well as groups to access information freely and easily without any boundaries. Vast amount of the sources support educational institutions to be more effective and productive for knowledge production to the society. In educational context, knowledge traditionally were created in the schools, universities, research centers, and similarly in private institutions.

Knowledge creation results collaborative actions in classrooms, lectures, and discussions that needed for educational practices. Student centered initiatives become new application areas in modern world of education which encourages them to adapt new critical and creative thinking to analyze and solve 
problems and as active learners to be part of knowledge society.

The components of critical thinking such as inference of the content, recognition of assumptions, deduction of unnecessary activities and eliminate potential biases, interpretation of analysis results and evaluation of the outcomes and arguments are all related with knowledge creation and construction.

Ghadirian explored and focused only learning effectiveness and perceptions of student's behavioral patterns of knowledge dimensions and cognitive processes for online discussions. The empirical research explores five knowledge dimensions and seven Cognitive Process Dimensions. According to results, students were primarily sharing knowledge dimensions and cognitive processes of metacognition and understanding [19].

The form of knowledge (explicit and implicit) converges with people's activities in individual and group base. Knowledge management could be seen in different forms in terms of dissemination of quality content among those stakeholders [3]. Most commonly impact on knowledge generation in educational context is interactivity, collaborative working, sharing the valuable information which requires large number of user participation, collection of the learner's insights, delivery methods of intelligence, participation of sharing would generate new valuable knowledge. Analyzing the concept and context give opportunities for people to be part of improvement in information seeking activities and generate new valuable results in knowledge accusation, dissemination and cognitive processes.

\section{Research Methodology}

The purpose of this study was to explore the relationship between critical thinking and creative potential. Therefore, hypothesis of this research formed as below;

\section{H1: Critical thinking and creative potential are correlated.}

H2: female average score in critical thinking total equals to the male average score in critical thinking total

H3: female average score in creative potential equals to the male average score in creative potential

\subsection{Measures}

Participants were asked to complete two tests in total where the first test was measuring creative potential and the second test measuring critical thinking skills.
To measure the level of creativity, the Kincher's creative potential scale was used. Critical thinking skills were measured using the structured questionnaire - Watson-Glaser Critical Thinking Appraisal tool. The measurement includes five dimensions of logical and analytical reasoning: Inference, Recognition of Assumptions, Deduction, Interpretation, and Evaluation of Arguments.

\subsection{Sample}

Data were collected among higher school students 18-19 years old in Ukraine. The survey was distributed to 220 students, 134 male (60.9 per cent), 86 female (39.1 per cent). Participants were invited to participate in the study on a voluntary basis. The tools delivered to the participants were in English language.

\subsection{Data Analysis and Results}

In order to achieve the purpose of this study and to test hypotheses, the SPSS software was used. Descriptive statistics was adopted to analyze the results of the preliminary test and to find out demographic characteristics of the sample.

Table 1. Descriptive statistics

\begin{tabular}{|c|c|c|c|c|}
\hline \multicolumn{5}{|c|}{ Descriptive Statistics } \\
\hline \multicolumn{2}{|l|}{ Gender } & \multirow{2}{*}{\begin{tabular}{|r|} 
Mean \\
9.72
\end{tabular}} & \multirow{2}{*}{$\begin{array}{l}\begin{array}{l}\text { Std. } \\
\text { Deviation }\end{array} \\
2.438\end{array}$} & \multirow{2}{*}{$\begin{array}{c}\mathrm{N} \\
86\end{array}$} \\
\hline Female & $\begin{array}{l}\text { Critical Thinking } \\
\text { Total }\end{array}$ & & & \\
\hline & $\begin{array}{l}\text { Creative } \\
\text { Potential } \\
\text { Total } \\
\end{array}$ & 24.42 & 9.634 & 86 \\
\hline \multirow[t]{2}{*}{ Male } & $\begin{array}{l}\text { Critical Thinking } \\
\text { Total } \\
\end{array}$ & 8.40 & 2.038 & 134 \\
\hline & $\begin{array}{l}\text { Creative } \\
\text { Potential } \\
\text { Total }\end{array}$ & 27.61 & 12.636 & 134 \\
\hline
\end{tabular}

Next significant step in statistical analysis was taken to explore if there were relationship between following variables; gender, critical thinking, and creative potential. The relationships between all those variables were investigated using Pearson correlation coefficient test. Preliminary analyses were performed to ensure no violation of the assumptions of normality, linearity and homoscedasticity. 
Table 2. Correlations of variables

\begin{tabular}{|c|c|c|c|c|}
\hline \multicolumn{5}{|c|}{ Correlation } \\
\hline & & Gender & $\begin{array}{l}\text { Critical } \\
\text { Thinking } \\
\text { Total }\end{array}$ & $\begin{array}{l}\text { Creativ } \\
\mathrm{e} \\
\text { Potenti } \\
\text { al } \\
\text { Total }\end{array}$ \\
\hline \multirow[t]{3}{*}{ Gender } & $\begin{array}{l}\text { Pearson } \\
\text { Correlati } \\
\text { on } \\
\end{array}$ & 1 & $-.281^{* * *}$ & $.134^{*}$ \\
\hline & $\begin{array}{l}\text { Sig. } \\
\text { tailed) }\end{array}$ & & .000 & .047 \\
\hline & $\mathrm{N}$ & 220 & 220 & 220 \\
\hline \multirow[t]{3}{*}{$\begin{array}{l}\text { Critical } \\
\text { Thinking } \\
\text { Total }\end{array}$} & $\begin{array}{l}\text { Pearson } \\
\text { Correlati } \\
\text { on } \\
\end{array}$ & $-.281^{* *}$ & 1 & -.058 \\
\hline & $\begin{array}{l}\text { Sig. (2- } \\
\text { tailed) }\end{array}$ & .000 & & .393 \\
\hline & $\mathrm{N}$ & 220 & 220 & 220 \\
\hline \multirow[t]{3}{*}{$\begin{array}{l}\text { Creative } \\
\text { Potential } \\
\text { Total }\end{array}$} & $\begin{array}{l}\text { Pearson } \\
\text { Correlati } \\
\text { on } \\
\end{array}$ & $.134^{*}$ & -.058 & 1 \\
\hline & $\begin{array}{l}\text { Sig. (2- } \\
\text { tailed) }\end{array}$ & .047 & .393 & \\
\hline & $\mathrm{N}$ & 220 & 220 & 220 \\
\hline
\end{tabular}

There was a strong negative correlation between gender and critical thinking, $r=-.281, \mathrm{n}=220, \mathrm{p}<0.05$, with association between being a woman and high levels of critical thinking. There was a strong positive correlation between gender and creative potential, $\mathrm{r}=.134, \mathrm{n}=220, \mathrm{p}<0.05$, with association between being a man and high levels of creative potential.

Table below contains statistical analysis of relationships between gender and scales in critical thinking.

Table 3.Bivariate Correlation

\begin{tabular}{|l|l|r|}
\hline \multicolumn{2}{|c|}{ Correlations } \\
\hline Critical Thinking & gender \\
\hline Inference & $\begin{array}{l}\text { Pearson } \\
\text { Correlation }\end{array}$ & $\mathbf{- . 1 4 5}$ \\
\cline { 2 - 3 } & Sig. (2-tailed) & $\mathbf{. 0 3 2}$ \\
\cline { 2 - 3 } & $\mathrm{N}$ & $\mathbf{2 2 0}$ \\
\hline
\end{tabular}

\begin{tabular}{|c|c|c|}
\hline \multirow[t]{3}{*}{$\begin{array}{l}\text { Recognition of } \\
\text { assumptions }\end{array}$} & $\begin{array}{l}\text { Pearson } \\
\text { Correlation }\end{array}$ & -.103 \\
\hline & Sig. (2-tailed) & .128 \\
\hline & $\mathrm{N}$ & 220 \\
\hline \multirow[t]{3}{*}{ Deduction } & $\begin{array}{l}\text { Pearson } \\
\text { Correlation }\end{array}$ & $-.282^{* *}$ \\
\hline & Sig. (2-tailed) & .000 \\
\hline & $\mathrm{N}$ & 220 \\
\hline \multirow[t]{3}{*}{ Interpretation } & $\begin{array}{l}\text { Pearson } \\
\text { Correlation }\end{array}$ & -.066 \\
\hline & Sig. (2-tailed) & .333 \\
\hline & $\mathrm{N}$ & 220 \\
\hline \multirow[t]{3}{*}{\begin{tabular}{|l} 
Evaluation of \\
Arguments
\end{tabular}} & $\begin{array}{l}\text { Pearson } \\
\text { Correlation }\end{array}$ & -.117 \\
\hline & Sig. (2-tailed) & .084 \\
\hline & $\mathrm{N}$ & 220 \\
\hline
\end{tabular}

The relationships between critical thinking and gender was investigated using Pearson productmoment correlation coefficient. There was a significant negative correlation between inference scale of critical thinking and gender, $r=-.14, n=220$, $\mathrm{p} \leq .0 .05$, with lower level of inference among male. There was a significant strong negative correlation between deduction scale of critical thinking and gender, $\mathrm{r}=-.28, \mathrm{n}=220, \mathrm{p} \leq .0 .01$, with lower level of deduction among male.

Table below contains statistical analysis of the relationships between scales in critical thinking and creative potential for two different groups: males and females.

Table 4. Correlations of variables

\begin{tabular}{|c|c|c|c|}
\hline \multicolumn{4}{|c|}{ Correlations } \\
\hline Gender & \multicolumn{2}{|l|}{ Critical Thinking } & \multirow{2}{*}{$\begin{array}{l}\begin{array}{r}\text { Creative } \\
\text { potential }\end{array} \\
\mathbf{. 1 9 2}\end{array}$} \\
\hline \multirow[t]{7}{*}{ Female } & \multirow[t]{3}{*}{ Inference } & $\begin{array}{l}\text { Pearson } \\
\text { Correlation }\end{array}$ & \\
\hline & & Sig. (2-tailed) & .076 \\
\hline & & $\mathrm{N}$ & 86 \\
\hline & \multirow[t]{3}{*}{$\begin{array}{l}\text { Recognition of } \\
\text { assumptions }\end{array}$} & $\begin{array}{l}\text { Pearson } \\
\text { Correlation }\end{array}$ & .018 \\
\hline & & Sig. (2-tailed) & .871 \\
\hline & & $\mathrm{N}$ & 86 \\
\hline & Deduction & $\begin{array}{l}\text { Pearson } \\
\text { Correlation }\end{array}$ & .050 \\
\hline
\end{tabular}




\begin{tabular}{|c|c|c|c|}
\hline & & Sig. (2-tailed) & .647 \\
\hline & & $\mathrm{N}$ & 86 \\
\hline & Interpretation & $\begin{array}{l}\text { Pearson } \\
\text { Correlation }\end{array}$ & -.045 \\
\hline & & Sig. (2-tailed) & .684 \\
\hline & & $\mathrm{N}$ & 86 \\
\hline & $\begin{array}{l}\text { Evaluation of } \\
\text { Arguments }\end{array}$ & $\begin{array}{l}\text { Pearson } \\
\text { Correlation }\end{array}$ & $.237^{*}$ \\
\hline & & Sig. (2-tailed) & .028 \\
\hline & & $\mathrm{N}$ & 86 \\
\hline Male & Inference & $\begin{array}{l}\text { Pearson } \\
\text { Correlation }\end{array}$ & $-.199 *$ \\
\hline & & Sig. (2-tailed) & .021 \\
\hline & & $\mathrm{N}$ & 134 \\
\hline & $\begin{array}{l}\text { Recognition of } \\
\text { assumptions }\end{array}$ & $\begin{array}{l}\text { Pearson } \\
\text { Correlation }\end{array}$ & $-.184^{*}$ \\
\hline & & Sig. (2-tailed) & .033 \\
\hline & & $\mathrm{N}$ & 134 \\
\hline & Deduction & $\begin{array}{l}\text { Pearson } \\
\text { Correlation }\end{array}$ & -.101 \\
\hline & & Sig. (2-tailed) & .247 \\
\hline & & $\mathrm{N}$ & 134 \\
\hline & Interpretation & $\begin{array}{l}\text { Pearson } \\
\text { Correlation }\end{array}$ & .070 \\
\hline & & Sig. (2-tailed) & .423 \\
\hline & & $\mathrm{N}$ & 134 \\
\hline & $\begin{array}{ll}\text { Evaluation of } \\
\text { Arguments }\end{array}$ & $\begin{array}{l}\text { Pearson } \\
\text { Correlation }\end{array}$ & -.017 \\
\hline & & Sig. (2-tailed) & .843 \\
\hline & & $\mathrm{N}$ & 134 \\
\hline
\end{tabular}

From the output given above, there were significant relationships between some of scales of critical thinking and creative potential in two groups of participants: female and male. The correlation between scale evaluation of arguments and creative potential positive affect for females was $r=.23, n=86$, $\mathrm{p} \leq .0 .05$, when higher level of creative potential associated with higher level in evaluation of arguments.

There is a significant negative correlation between scales in critical thinking and creative potential for males: the correlation between Inference and Creative potential was $\mathrm{r}=-.19, \mathrm{n}=134, \mathrm{p} \leq .0 .05$, when the higher level of inference is associated with lower level of creative potential.

The correlation between recognition of assumptions and creative potential was $\mathrm{r}=-.18, \mathrm{n}=134$, $\mathrm{p} \leq .0 .05$, when the higher level of assumption's recognition is associated with lower level of creative potential.

\section{Discussions}

In this study, it has been taken an important step in examining the relationships between critical thinking and creativity in order to gain a deeper insight into the key factors that influence individual cognitive abilities among young generation in Ukraine. Based on a sample of 220 young people participated in empirical study, the specific relationships were confirmed in line with the previous studies as well as the hypothesized gender influence on the level of critical thinking and creativity [2], [5].

Table 1 shows the difference between mean for each variable (gender, critical thinking, and creative potential) in two groups: males and females. The relationships between all of these variables were investigated using Pearson Correlation Coefficient.

Table 2 demonstrated that the correlation between gender and critical thinking is significant and negative $(r=-.281)$, while the correlation between gender and creative potential is significant and positive $(r=.134)$.

Table 3 showed that the negative correlation between inference scale of critical thinking and gender is significant and negative ( $\mathrm{r}=-.145)$. Inference is a critical thinking skill which requires from a person to read "between lines", to combine analyzed information from provided text with own knowledge and experience in order to be able to provide conclusions. According to the results, the inference level was lower among males. It has been also shown that the correlation between deduction scale of critical thinking and gender was significant and negative $(r=-$ .282). Deduction is related to providing an argument with applying premises in order to prove the conclusion. Results showed that the level of deduction was lower among males.

Table 4 demonstrated that the correlation between evaluation of arguments and creative potential is positive for females was $(r=.237)$. Female students with higher level of creative potential have with higher level evaluation of arguments. It showed also that the correlation between inference and creative potential was significant and negative ( $\mathrm{r}=-.199)$. Male students with higher level of inference have lower level of creative potential.

It has been shown that the correlation between recognition of assumptions and creative potential was negative $(\mathrm{r}=-.184)$. Male students with the higher level of assumption's recognition possess lower level of creative potential. 
According to obtained results of the research, gender has been found to be significant showing correlation between measured variables with a difference in its direction.

Obtained results are in line with some of mentioned above studies, showing that female scored higher than males in some of critical thinking scales [20], as well as at high level critical thinking skills ability [18]. Some of other studies stated that there is no gender differences in critical thinking scales [1], therefore critical thinking is related to the process of gaining experience or knowledge generation.

There is a significant gender difference in creativity among students participated in this research. Current study shows the higher level of creative potential among males. This is not in agreement with other studies showing that females have higher creativity than males. But it should be considered that the data showing gender difference might become smaller with the age. [4].

The statistical analysis did not support the hypothesis about the significant relationships between critical thinking and creative potential. It was not proved that the critical thinking and creativity are significantly interrelated. Therefore, $H 1$ is not accepted. On the other hand, $H 2$ and $H 3$ accepted. According to analysis results which have been proved that gender has a significant influence on the level of critical thinking and creativity among young generation.

\section{Conclusions}

Authors attempted to explore the relationships between critical thinking and creativity from both theoretical and empirical points of view. Presented and discussed results are considered as preliminary study and they are going to be explored in different further studies. The primary findings of the study shows that existing relationships between all studied constructs are complex and influenced by other variables such as personality, social environment, educational system, technology usage and knowledge generation, teacher's philosophy etc. Mentioned variables will be included in planned studies in order to investigate the relationships between critical thinking and creativity in more complex way. Further studies would be more concentrated on the effect and impact of different variables in order to investigate the relationship.

Knowledge generation and dissemination are affected by various behavioral patterns and cognitive processes. Those effects primarily found on the research results of this study which were inference, deduction, interpretation recognition of assumptions and evaluation of arguments. Critical thinking and creativity are important sources of knowledge generation for individuals as well as the groups. Although results of this study were not proved the relationship between critical thinking and creativity significantly, but the knowledge generation is a process of combined both approaches. In order to generate new knowledge for certain issues, the analytic problem solving methods used with critical thinking ensures for better results. Moreover creative approaches play essential role to gain context specific knowledge for innovative ideas and results. The level of knowledge and its form depends on the content and the context of educational needs.

This research has some limitations. It could be related to sample descriptions or social environments of participating young generation to the study. However, the self-beliefs of students and teachers approach seems to be significant variables influencing the development and quality of the relationship between critical thinking and creativity with gender differences.

\section{References}

[1] Bagheri, F. \& Ghanizadah, A. (2016). Critical thinking and gender differences in academic self-regulation in higher education. Journal of Applied Linguistics and Language Research, 3 (3), 133-145.

[2] Bailin, S. (1987). Critical and Creative Thinking. Informal Logic. 11, 1, 23-30.

[3] Kulakli, A, and Mahony, S. (2014). Knowledge creation and sharing with Web 2.0 tools for teaching and learning roles in so-called University 2.0. Procedia-Social and Behavioral Sciences, 150, 648-657.

[4] Bart, W., Hokason, B., Sahin, I., Abdelsames, M. (2015). An investigation of the gender differences in creative thinking abilities among $8^{\text {th }}$ and $11^{\text {th }}$ grade students. Thinking Skills and Creativity, 17, 17-24.

[5] Paul, R. W., \& Elder, L. (2006). Critical thinking: The nature of critical and creative thought. Journal of Developmental Education, 30(2), 34-35

[6] Plucker, J.A., Beghetto, R.A., Dow, G.T. (2004). Why isn't creativity more important to educational psychologists? Potentials, Pitfalls, and Future Directions in Creativity Research, Educational Psychologist, 39:2, 83-96, DOI: $10.1207 / \mathrm{s} 1532698$ ep3902_1

[7] Richardson, V. (2003). Preservice teachers' beliefs. In J. Raths and A.C. McAninch (Eds.), Teacher beliefs and classroom performance: The impact of teacher education. Greenwich, CT: Information Age Publishing.

[8] Runco, M. A. (2004), Creativity, Annual Review of Psychology, I, 657-687.

[9] Shubina I., (2017). Creativity in psychotherapy: the possibilities of its utilization. The European Proceeding of Social \& Behavioural Sciences. XXII, 99-111. eISSN:23571330.

[10] Cujbă, T.O. (2010). Considerations on Creativity Motivation. Buletinul Universitanii Petrol - Gaze din Ploiesti. Stiinele Educaniei. Vol. LXII (2), 154 - 159 
[11] Kaufaman, J.C. \& Beghetto, R.A. (2009). Beyond big and little: the four $\mathrm{C}$ model of creativity. Review of General Psychology, 13, 1-12.

[12] Sternberg, R.J. (2002). Raising the achievement of all students: teaching for successful intelligence. Educational Psychology Review, 14, 383-393

[13] Shubina, I. and Kulakli, A. (2019). Pervasive learning and technology usage for creativity development in education. International Journal of Emerging Technologies in Learning (iJET), 14 (1), pp 95-109

[14] Shubina, I., Kulakli, A., Plakhotnik, O. (2018). Critical thinking and creativity: complimentary or dissonant relationship. Proceedings of London International Conference on Education (LICE 2018) by Infonomics Society, pp.192-195

[15] Torrance, E. P. (1983). Status of creative women: Past, present, and future. The Creative Child and Adult Quarterly, $8(3), 135-145$.

[16] Collins, M.A., \& Amabile, T.M. (1999). Motivation and creativity. In R.J. Sternberg (Ed.), Handbook of creativity (pp.297-312). Cambridge: Cambridge University Press.

[17] OECD (Organisation for Economic Cooperation and Development) 2009. Assessment Framework. Programme for the International Students Assessment. Vol. 1. Pisa.

[18] Zetriuslita, HJ, Ariawan, R., \& Nufus, H. (2016). Students' Critical Thinking Ability: Description Based on Academic Level and Gender. Journal of Education and Practice, 7 (12), 154-164.

[19] Ghadirian H., Salehi K., Ayub A.F.M. (2018). Exploring the behavioural patterns of knowledge dimensions and cognitive processes in peer-moderated asynchronous online discussions. The International Journal of E-Learning \& Distance Education, Vol33, (1)

[20] Walsh, C. \& Hardy, R. (1999). Dispositional differences in critical thinking related to gender and academic major. Journal of Nursing Education, 38, 149155 . 